\title{
河道網特性と貯留関数法に関する研究
}

舘谷 清* ・藤田睦博**

\section{Study on the Relation of Storage-Discharge Model to Channel Net work Characteristics}

\author{
Kiyoshi Tateya* and Mutsuhiro Fujita**
}

\begin{abstract}
Various types of the lumped runoff model have been treated for practical uses. For example, the so- called storage function model, i.e. the model based on storage-discharge relationship, has been widely accepted. The characteristics of the storage function model have been examined empirically in several of the actual watersheds. These have also been discussed theoretically with the help of the kinematic wave method on the mountainside.

However, in the channel regions, the discharge depends on the characteristics of the channel networks. This paper shows that parameters of the storage function model can be estimated by the characteristics of channel networks and the flow velocity.
\end{abstract}

Key words : Storage-Discharge Relationship, Channel Networks, Link-Magnitude

実用的な流出解析手法として集中定数系の流出モデルが用いられている. 眝留関数法は，その代表的手法の一つである。これま で, 眝留関数法に含まれるパラメー夕の評価法としてKinematic Wave法に基づく成果が発表されている.これらは何れも斜面流 域を対象としている。本論文は, 河道網における斜面流域からの流出量の集水過程をリンク〜マグニチュード方式に基づく河道網 理論の立場から論じ，貯留関数法に含まれるパラメータ值と河道網特性の関係について考察したものである.

キーワード：眝留関数, 河道ネットワーク, リンクーマグニチュード

\section{I。はじめに}

流域は斜面と河道の 2 要素から構成されている。斜面 は降雨量を流量に変換する場であり，河道は斜面からの 流出量を合成，運搬する場である，流域の形状や輪郭が 流出量に影響するということは,ごく早い時期に Sherman'によよって指摘されている。 その後, Horton ${ }^{2)}$, Strahler ${ }^{3}$ らによって提案された河道位数化理論に基づ く地形則が水文学の分野に導入された。例えば，分畦比 の大小によって流出形態を分類する試みも提案されてい るが，定性的な段階にとどまっているい．一方，我国にお いても石原，高棹ららによって河道配列構造に関する先 駆的な研究がなきれている，以上の研究は，河道の位数

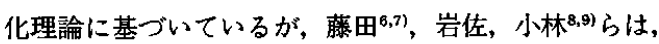
位数化理論では高位河道に低位の河道が合流しても位数 に変化がなく，河道の合流にともなう連続関係の成立し ない不合理性を指摘して, リンク〜マグニチュード理論 の利用を提案している。

一方, 貯留関数法は実流域における流出解析法の代表
的手法の一つである、これまで，貯留関数法に含まれる パラメー夕值と流域特性を関連づけようとする試みがな されているが, 斜面流域を対象とした解析が多い10,11!.

本論文は河道網における集水過程に貯留関数法を適用 した、すなわち、これまでに得られている河道網理論の 成果に基づいて，貯留関数法に含まれる代表的なパラ メータである貯留係数, 遅れ時間などの評価を行なった。

$$
\begin{aligned}
& \text { II. リンク〜マグニチュード理論に } \\
& \text { 基つく河道網特性 }
\end{aligned}
$$

河道網を形成する最大の営力は雨水の作用である，河 道網形成の期間を考えるならば，相当広範囲の地域にわ たって降雨量が等分布していると仮定できる、したがっ て, 現在の河道網特性は, 専ら流域の地形, 地質および 地被物（植生等も含む）等の諸要素の総合的な影笠を反 映しているものと考えられる.

リンク〜マグニチュード理論は、水源を有する河道を 外部リンク, 合流点間を結ぶ河道を内部りンクと区別す るもので, 河道網内に含まれる外部リンク数をマグニ チュードと呼んでいる. 左支川，右支川の区別をしない と,図ー 1 に示すような河道網配列パターンを得る.（）

*(財)北海道河川防災研究センター 
の数值は各パターンの生起確率を示している.この生起 確率は次のように得られる. 河道網を形成する営力が流 域全体にわたって等分布しているならば，河道が新しく 発生する確立はどのリンクにおいても均一と考えられ る. 例之ば，图ー2ではマグニチュード 3 の河道網に新 しく河道が発生して(破線の河道) マグニチュード4の 河道網になる過程を説明している，5通りの組み合わせ があり、これを整理すると図の下段の河道網となり, 確 立 $4 / 5 ， 1 / 5$ を得る. マグニチュードNの河道網に おいて（以後 $Z=N$ の河道網あるいは $Z=N$ の流城と呼 ぶ異なる河道網パターン数 $\mathrm{S}_{\mathrm{N}}$ 、, 次式で与えられる。

$$
\mathrm{S}_{\mathrm{N}}=\left\{\begin{array}{lr}
\sum_{i=1}^{i \mathrm{~N} / 2]} \mathrm{S}_{i} \mathrm{~S}_{\mathrm{N}-i} & (\mathrm{~N} \neq 2 \mathrm{~m}) \\
\sum_{i=1}^{m-1} \mathrm{~S}_{i} \mathrm{~S}_{2 m-i}+\frac{1}{2} \mathrm{~S}_{m}\left(1+\mathrm{S}_{m}\right) & (1) \\
& (\mathrm{N}=2 \mathrm{~m})
\end{array}\right.
$$

[ ]：がウス記号
実河道網において河道網の配列パターンを実測し，そ の頻度分布が困一1の生起確率分布に類似していると流 域の地形, 地質, 地被物等の諸要素を総合した流域特性 が流域全体にわたって均一であると判断される。しかし ながら，Nの增大にともないパターン数は幾何級数的に 增大し，実用的には四ー1に示すような個々のパターン の生起確率を対象にするのではなく，図ー3に示すよう $に Z=N$ の河道網の最下流の合流点において河道網を二 つの河道網に分割し，それぞれ二つの河道網のマグニ チュードが $\mathrm{i} ， \mathrm{~N}$ - i となるパターンの確率 $\mathrm{P}(\mathrm{i}, \mathrm{N})$ が重要となる。

$\mathrm{P}(\mathrm{i}, \mathrm{N})=\frac{\mathrm{N}}{2 \mathrm{~N}-3}$

$$
\begin{aligned}
& \mathrm{P}(1, \mathrm{~N})=\frac{2(2 \mathrm{i}-3) ! \mathrm{N} !(\mathrm{N}-2) !(2 \mathrm{~N}-2 \mathrm{i}-2) !}{(\mathrm{i}-2) ! \mathrm{i} !(\mathrm{N}-\mathrm{i}) !(2 \mathrm{~N}-3) !(\mathrm{N}-\mathrm{i}-1) !} \\
& 2 \leqq \mathrm{i} \leqq[\mathrm{N} / 2], \mathrm{N} \neq 2 \mathrm{~m} \\
& \mathrm{P}(\mathrm{m}, 2 \mathrm{~m})=\frac{8 \mathrm{~m}}{(4 \mathrm{~m}-2) !}\left\{\frac{(2 \mathrm{~m}-1) !(2 \mathrm{~m}-3) !}{\mathrm{m} !(\mathrm{m}-2) !}\right\}^{2}
\end{aligned}
$$

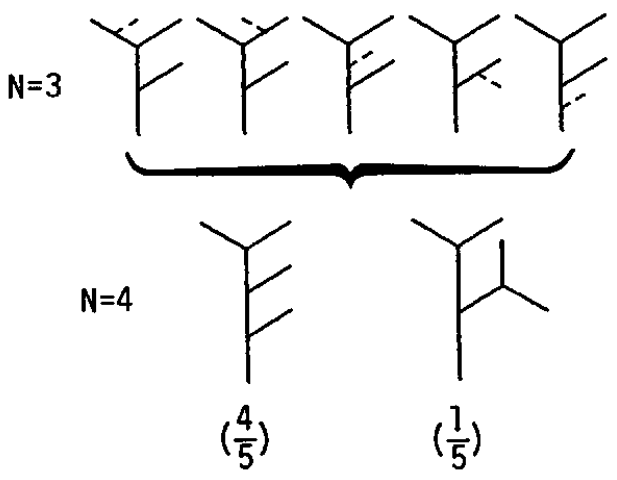

泟

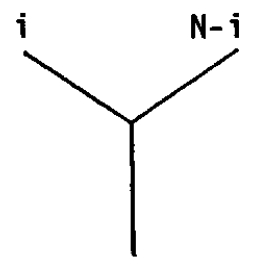

図-3 
一方，図ー4に示すように本流に合流する支流数は， 图ー1に示されているよjに各パターン毎に様々であ る. $Z=N$ の河道網における平均支流数 $M_{N}$ は次式により 求まる。

$$
\begin{aligned}
& \overline{\mathrm{M}}_{\mathrm{N}}=\sum_{i=1}^{[\mathrm{N} / 2]} \mathrm{P}(\mathrm{i}, \mathrm{N})\left(\mathrm{M}_{\mathrm{N}-i}+1\right) \\
& \overline{\mathrm{M}}_{\mathrm{l}}=\overline{\mathrm{M}}_{2}=1, \overline{\mathrm{M}}_{3}=2, \mathrm{~N} \geqq 4 \\
& \overline{\mathrm{M}}_{1}=0, \overline{\mathrm{M}}_{2}=1, \overline{\mathrm{M}}_{3}=2
\end{aligned}
$$

ここでは，最下流の合流点からマグニチュードのより 大きい河道を期ることにより本流を定義している. 図一 4 を参照すると本流長は $\overline{\mathrm{M}}_{\mathrm{N}}$ 個の内部リンクと 1 個の外 部リンクより構成されている. 内部リンク長, 外部リン ク長のそれぞれの平均值を $\overline{\mathrm{L}}_{i n}, \overline{\mathrm{L}}_{\mathrm{ex}}$ とすると平均本流長 L出は次のようになる。

$$
\overline{\mathrm{L}}_{\mathrm{M}}=\overline{\mathrm{L}}_{e x}+\overline{\mathrm{M}}_{\mathrm{N}} \cdot \overline{\mathrm{L}}_{\text {in }}
$$

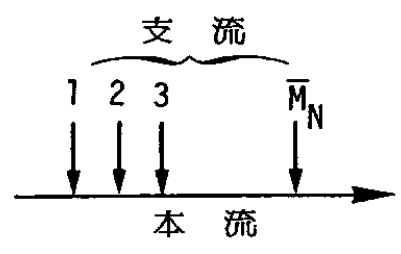

図一 4

一方, $Z=\mathrm{N}$ の河道網は $\mathrm{N}$ 個の外部リンクと $(\mathrm{N}-1)$ 個の内部リンクよりなっており，これら内部リンクに付 随している平均流域面積を $\overline{\mathrm{A}}_{i n}, \overline{\mathrm{A}}_{e x}$ と $\mathrm{Z}=\mathrm{N}$ の流域の総 面積 $\mathrm{A}_{t}$ は，次式で与えられる。

$$
\mathrm{A}_{t}=\left(\overline{\mathrm{A}}_{\text {in }}+\overline{\mathrm{A}}_{e x}\right) \mathrm{N}-\overline{\mathrm{A}}_{\text {in }} .
$$

本流長と集水面積間の関係式として次のHackの式が 知られている。

$$
\mathrm{L}_{\mathrm{M}}=\alpha \mathrm{A}_{t}
$$

$\alpha$ は定数で, $\beta$ は多くの流域で $0.5 \sim 0.6$ 值をとると

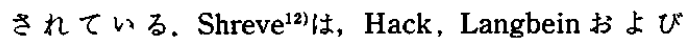
Leopoldらの実測值を整理して図ー 5 を示している. $\beta$ の 值は中小流域 $\left(1 \sim 10^{3} \mathrm{~km}^{\mathrm{n}}\right)$ において 0.6 程度の值をとり, 流域面積の増大 $\left.\left(10^{3} \sim 10^{7} \mathrm{~km}\right)^{7}\right)$ にともない $\beta$ は 0.5 程度ま で減少している.

一方, 式(4)，(5)において, $\overline{\mathrm{L}}_{i n}=\overline{\mathrm{L}}_{e x}=\overline{\mathrm{L}}, \overline{\mathrm{A}}_{\text {in }}=$ $\overline{\mathrm{A}}_{e x}=\overline{\mathrm{A}}$ とすると，式（4)、（5）より次式を得る.

$$
\overline{\mathrm{L}}_{\mathrm{M}}=\left(1+\overline{\mathrm{M}}_{\mathrm{N}}\right) \overline{\mathrm{L}}
$$

$$
\overline{\mathrm{A}}_{t}=(2 \mathrm{~N}-1) \overline{\mathrm{A}}
$$

となる.図一 6は, $\overline{\mathrm{L}}=1, \overline{\mathrm{A}}=1$ として $\mathrm{A}_{t}$ と $\overline{\mathrm{L}}_{\mathrm{M}}$ の関保 をプロットしたものである，図ー5の実測值の傾向を説 明していることがわかる.

式（6）のHackの式として式（9）を用いる ${ }^{13)}$.

$$
\begin{aligned}
& \mathrm{L}_{M}=1.273 \mathrm{~A}_{t}{ }^{0.6} \\
& \mathrm{~L}_{\mathrm{M}}: \text { 本流長 }(\mathrm{km}), \mathrm{A}_{t} \text { : 集水面積 }\left(\mathrm{m}^{*}\right)
\end{aligned}
$$

$\overline{\mathrm{L}}_{\mathrm{M}}=\mathrm{L}_{\mathrm{M}}$ と仮定し，実流域における流域面積 $\mathrm{A}_{t}$, マグ

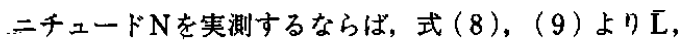
六を求めることができる.

$$
\begin{aligned}
& \overline{\mathrm{L}}=\frac{1.273 \mathrm{~A}_{t}^{0.6}}{\left(\mathrm{M}_{\mathrm{N}}+1\right)}=\frac{1.273 \mathrm{At}^{0.6}}{\left(\mathrm{M}_{\mathrm{N}}+1\right)} \\
& \overline{\mathrm{A}}=\frac{\mathrm{A}_{\mathrm{t}}}{2 \mathrm{~N}-1}
\end{aligned}
$$

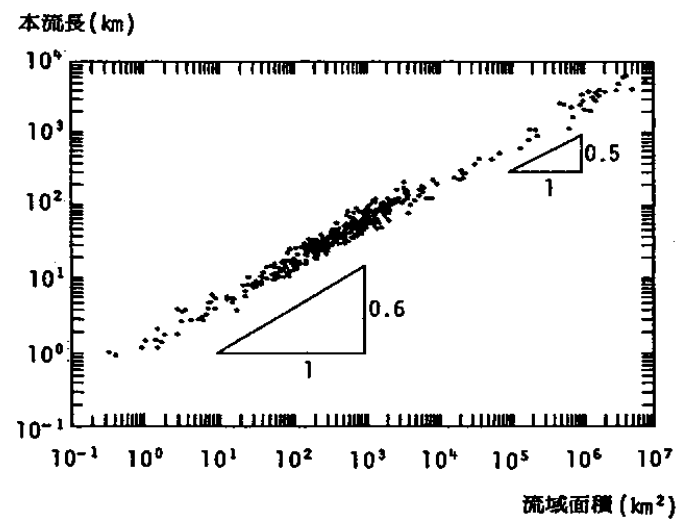

図一 5

$\bar{M}_{N}+1$

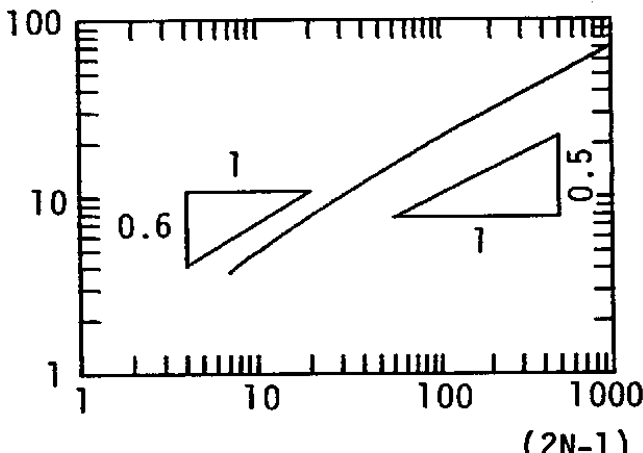

图-6 
表 1 は, 北海道内の留萌川, 後利志別川, 渚滑川を 対象に地形図より実測した河道網の特性量と上述の河道 網理論より得られた結果と比較したものである，同一の 流域であっても地形図の縮尺が異なると河道網のマグニ チュードも異なるので $1 / 2.5$ 万，1 $1 / 5$ 万地形図及び国 土地理院で整備されている国土数值情報 (K S - 272, K $\mathrm{S}-273 ， 1 / 20$ 万地形図相当）を用いて比較検討した. 地形図の河道は, 平水時流水幅 $1.5 \mathrm{~m}$ 以上, 図上長 1 $\mathrm{cm}$ （1 / 1 万地形図）あるいは, 図上長 $2 \mathrm{~cm} （ 1 / 5$ 万
地形図）以上の河道を対象としている，地形図上での測 定にあたって，地形図に表示されている河道の上流端を 水源の位置とした，地形図に示されている水線記号のみ を河道と認めると $\overline{\mathrm{A}}_{e x}, \overline{\mathrm{L}}_{e x}$ の方が $\overline{\mathrm{A}}_{i n}, \overline{\mathrm{L}}_{\text {in }}$ り大きく評 価されることになる.表一 1 にもその傾向が認められる. しかし，後述するように以後の解析に最も重要な平均内 部リンク長 $\overline{\mathrm{L}}_{\text {in }}$ に関して, 式 (10)に推定值と実測值がよ く一致していることがわかる.

\section{表一 1 河道網理論と実測值の比較}

\begin{tabular}{|c|c|c|c|c|c|c|c|c|c|c|c|c|}
\hline \multirow[b]{3}{*}{ 流城 名 } & \multicolumn{2}{|c|}{ 留 或 } & \multicolumn{2}{|c|}{ 川 } & \multicolumn{4}{|c|}{ 後志利别川 } & \multicolumn{4}{|c|}{ 清 川 } \\
\hline & \multicolumn{2}{|c|}{ 国土数值情辑 } & \multicolumn{2}{|c|}{$1 / 25,000$ 地形圆 } & \multicolumn{2}{|c|}{ 国土数值情叝 } & \multicolumn{2}{|c|}{$1 / 50,000$ 地形图 } & \multicolumn{2}{|c|}{ 国土数情情韧 } & \multicolumn{2}{|c|}{ 1/50,000地形圆 } \\
\hline & 実 清 & 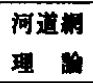 & 実 现 & $\begin{array}{l}\text { 河道䋨 } \\
\text { 理 調 }\end{array}$ & 実 湖 & $\begin{array}{l}\text { 河道洞 } \\
\text { 理 }\end{array}$ & 实 朗 & $\begin{array}{l}\text { 河道糟 } \\
\text { 理 部 }\end{array}$ & 实 㨽 & 河道䌃 & 寒 䍖 & 河道策 \\
\hline 流城面稓( & 268.7 & & 276.2 & & 705.2 & & 714.7 & & 1231.8 & & 1229.2 & \\
\hline 本沙長 (ka) & 42.8 & 36.5 & 34.2 & 37.1 & 75.2 & 65.1 & 73.2 & 65.7 & 71.1 & 91.0 & 84.7 & 90.9 \\
\hline $\begin{array}{l}\text { 本湳に合流する } \\
\text { 支流数 }\end{array}$ & 11 & 8.4 & 24 & 23.1 & 22 & 16.7 & 32 & 36.1 & 24 & 21.5 & 53 & 48.6 \\
\hline 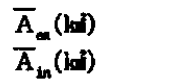 & $\begin{array}{r}13.7 \\
5.8\end{array}$ & 10.0 & $\begin{array}{l}2.3 \\
1.9\end{array}$ & 2.1 & $\begin{array}{r}14.0 \\
4.3\end{array}$ & 9.2 & $\begin{array}{l}2.3 \\
2.6\end{array}$ & 2.5 & $\begin{array}{r}12.6 \\
8.6\end{array}$ & 10.5 & $\begin{array}{l}2.8 \\
2.1\end{array}$ & 2.5 \\
\hline $\begin{array}{l}\bar{L}_{a k}(\mathrm{l}) \\
\overline{\mathrm{L}}_{\mathrm{in}}(\mathrm{l})\end{array}$ & $\begin{array}{l}8.6 \\
3.8\end{array}$ & 3.9 & $\begin{array}{l}1.9 \\
1.8\end{array}$ & 1.5 & $\begin{array}{r}10.4 \\
2.7\end{array}$ & 3.7 & $\begin{array}{l}1.7 \\
2.1\end{array}$ & 1.8 & $\begin{array}{l}7.8 \\
3.6\end{array}$ & 3.8 & $\begin{array}{l}2.0 \\
1.6\end{array}$ & 1,6 \\
\hline マグニチュード & 14 & & 67 & & 39 & & 146 & & 59 & & 251 & \\
\hline $\begin{array}{c}\text { 平均河道長 (h) } \\
\mathrm{L}_{\mathbf{M E}}\end{array}$ & 18.3 & 19.2 & 23.6 & 19.6 & 22.9 & 34.3 & 30.2 & 34.6 & 41.6 & 48.0 & 49.4 & 47.9 \\
\hline
\end{tabular}

\section{III. 河道網における策水過程}

集水過程を考える場合, 図一 7 に示すように河道網の 末端から等しいリンク数だけ離れている小流城数を求め ると便利である。ここで小流域は各リンクに付随してい る流域と定義している、図はマグニチュード4の河道網 を対象にしており，リンク A， B，C，Dは河道網の末 端よりそれぞれ 4，3，2，1個だけリンクを遡った位 置にある.このようなリンク数は，対象とする河道網の マグニチュードあるいは図ー1に示すように各河道網パ ターンによって様々である，C $(\mathrm{N}, \mathrm{J})$ をマグニチュー ドNの河道網において，河道網末端より J 個だけりンク

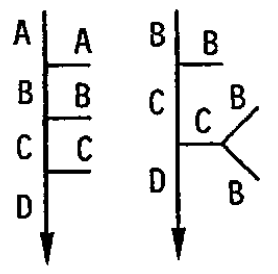

図一 7 を邀った位置にある平均小流域数と定義すると、次式を 得る. 


$$
\begin{aligned}
\mathrm{C}(\mathrm{N}, \mathrm{J}+\mathrm{1})= & \sum_{\mathrm{i}=1}^{[\mathrm{N} / 2]} \mathrm{P}(\mathrm{i}, \mathrm{N})\{\mathrm{C}(\mathrm{i}, \mathrm{J}) \\
& +\mathrm{C}(\mathrm{N}-\mathrm{i}, \mathrm{J})\}
\end{aligned}
$$

$2 \leqq \mathrm{~J} \leqq \mathrm{~N}-1, \mathrm{~N} \geqq 4$

$\mathrm{C}(\mathrm{N}, 1)=1, \mathrm{C}(\mathrm{N}, 2)=2$,

$\mathrm{C}(\mathrm{N}, \mathrm{J})=0, \mathrm{~N}<\mathrm{J}$

マグニチュードNの河道網は（2 N-1）個のリンク

より構成されているので，C（N，J）は次式を満足し ている。

$$
\sum_{\mathrm{j}=1}^{\mathrm{N}} \mathrm{C}(\mathrm{N}, \mathrm{J})=2 \mathrm{~N}-1
$$

図一8は，C（N，J）の計算結果を示している，J の值は流域末端からの河道長に比例し， C（N，J）は 流域面樌に比例すると考えられるので，目一 8 をZ=N の流域の平均面樌集中図とも解釈できる.

各リンクに付随している小流域を単位流域と考え，単
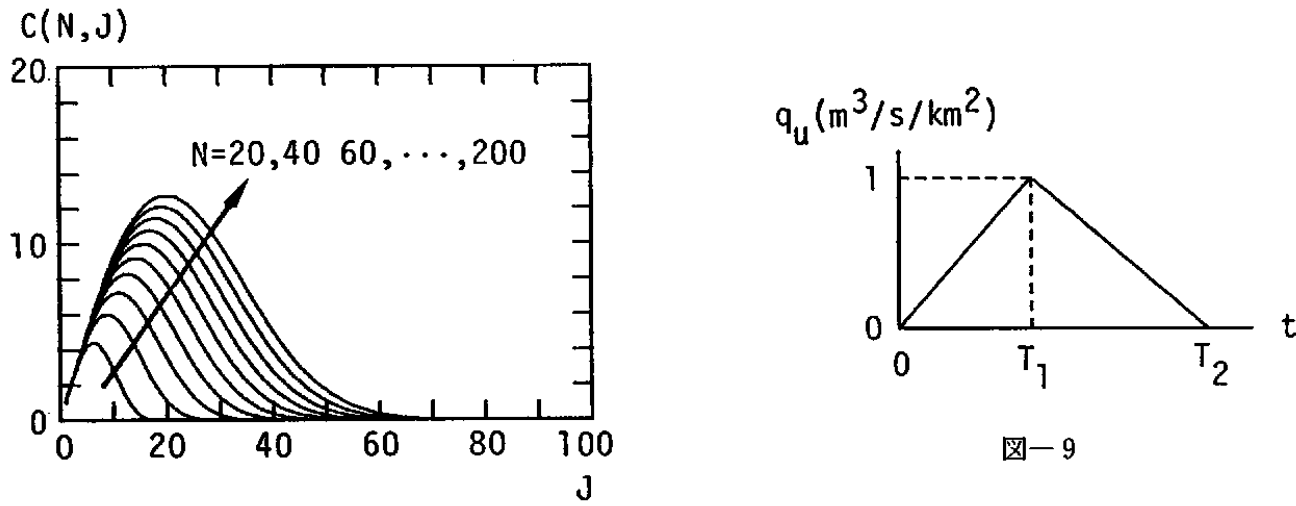

図-9
位流域からの比流量 $\mathrm{qu}_{\mathrm{u}}(\mathrm{t})\left(\mathrm{m}^{3} / \mathrm{sec} / \mathrm{km}^{*}\right)$ が河道を一 定の伝播速度Vで流下するものと仮定すると，マグニ チュード $\mathrm{N}$ の流域末端における流量 $\mathrm{Q}(\mathrm{t}) （ \mathrm{~m} / \mathrm{sec})$ は $\mathrm{C}(\mathrm{N}, \mathrm{J})$ を用いると次の様になる。

$$
\mathrm{Q}(\mathrm{t})=\overline{\mathrm{A}} \sum_{\mathrm{J}=1}^{\mathrm{N}} \mathrm{q}_{\mathrm{u}}\left(\mathrm{t}-\frac{(\mathrm{J}-1) \mathrm{L}}{\mathrm{V}}\right) \mathrm{C}(\mathrm{N}, \mathrm{J})
$$

A，Lは式 (10)，(11) で与えられる。一方，マグニ チュードNの実河道網に関して次式を得る.

$$
Q(t)=\sum_{i=1}^{2 N-1} A_{1} q_{u}\left(t-\frac{L_{1}}{V}\right)
$$

ここに, $\mathrm{A}_{i}$ は $\mathrm{i}$ 番目の単位流域の面積, $\mathrm{L}_{i}$ は単位流域 の出口から流域末端まで到る距離である、 $\mathrm{qu}_{\mathrm{u}}(\mathrm{t})$ として 図ー9に示す三角形の流出ハイドログラフを与え，表一 1 の各流域を対象に式 (14)，(15) の計算結果 $\left(T_{1}=10\right.$, $\mathrm{T}_{2}=20 \mathrm{hr}$ ）を図-10・11に示す.

図-8

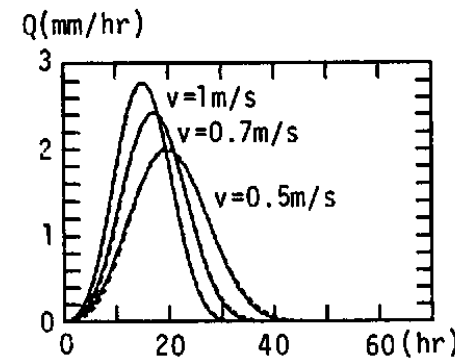

留萌川

契線：N=14 破線: $N=67$

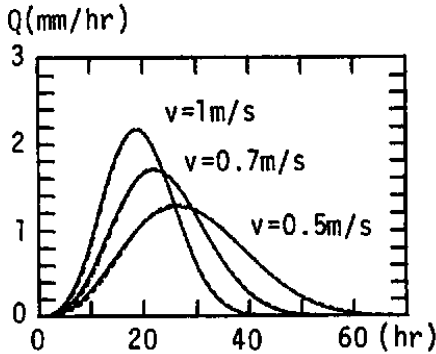

後志利別川 実線：N=39 破線； $N=146$

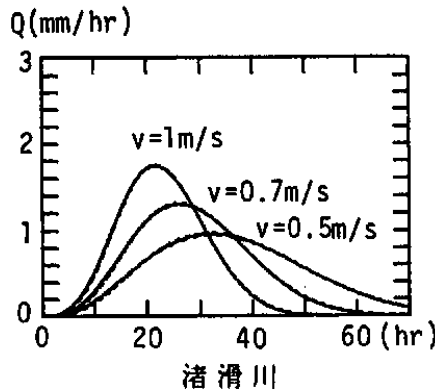

実線: $N=59$ 破線: $N=251$

図-10 


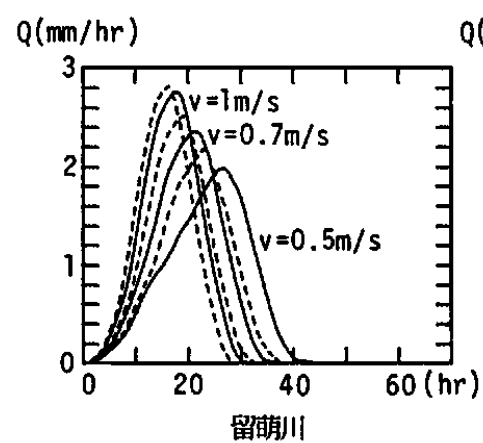

実線: $N=14$ 破線: $N=67$

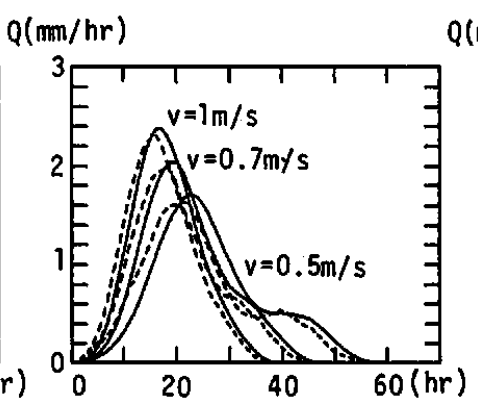

後志利別川

実線: $N=39$ 破線： $N=146$

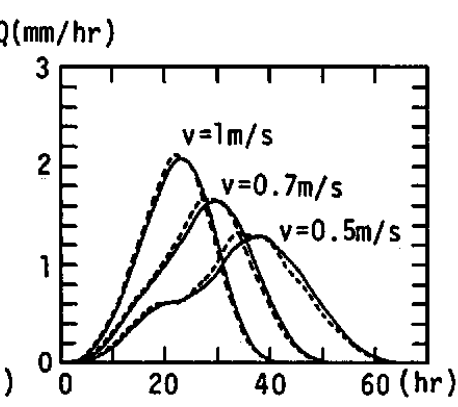

渚滑川

目-11

式（14）を用いた計算では，洪水流の伝播速度 $\mathrm{V} の$ 值 によってQ（t）が異なっているが，マグニチュードN の值にQ（t）が存在していないことを示している.

式（15）を用いた計算は，実河道網を対象としている ので，伝播速度の他に河道網のマグニチュード（地形図 の縮尺に依存）によりQ（t）が異なっている. 逆に言 之ば, 式（14）は地形図の縮尺に依存しない普遍的な河 道網における集水過程を記述しているものと解釈でき る.

一方, 実流域の流出解析法として貯留関数は，本邦で 採用されている代表的手法の一つである. 周知のように 眝留量 $\mathrm{S}_{\imath}(\mathrm{t})$, およU゙眝留関数は次のように与えられ る.

$$
\begin{aligned}
& \mathrm{S}_{l}(\mathrm{t})=\int_{0}^{\mathrm{t}-\mathrm{t}_{t}} \mathrm{r}(\mathrm{t}) \mathrm{dt}-\int_{0}^{\mathrm{t}} \mathrm{Q}_{\mathrm{h}}(\mathrm{t}) \mathrm{dt} \\
& \mathrm{S}_{l}(\mathrm{t})=\mathrm{KQ} \mathrm{Q}^{\mathrm{P}}
\end{aligned}
$$

ここに, $\mathrm{r}(\mathrm{t}), \mathrm{Q}_{n}(\mathrm{t})$ は降雨強度と流出高である. $r(t) と し て$, 単位流城加ら比流量 $q_{u}(t)$ を用い る.

$$
\begin{aligned}
& \mathrm{r}(\mathrm{t})=3.6 \mathrm{q}_{u}(\mathrm{t}) \quad(\mathrm{mm} / \mathrm{hr}) \\
& \mathrm{Q}_{\mathrm{h}}(\mathrm{t})=\frac{3.6}{(2 \mathrm{~N}-1) \bar{A}^{\mathrm{Q}}} \mathrm{Q}(\mathrm{t})(\mathrm{mm} / \mathrm{hr})
\end{aligned}
$$

数值計算で遅れ時間 $\mathrm{t}$, 眝留係数 $\mathrm{K}$, 及U゙眝留指数 $\mathrm{P}$ の最总解を求めた結果を以下に示す。最適解は, 通常行 なわれているように $\mathrm{S}_{\iota}(\mathrm{t}) \sim \mathrm{Q}_{h}(\mathrm{t})$ 曲線のループを なるへく偏平化するように $\mathrm{t}$ 、を定め, その後の $\mathrm{K} ， \mathrm{P}$ 求めた。まず, 計算にあたっては, 流域面穔 $\mathrm{A}_{t}$ 。伝播速 度 V $(0.5 \sim 1.0 \mathrm{~m} / \mathrm{sec})$ と適当なマグニチュードを与え て（式（14）は，マグニチュードNに依存しないことを 先に確かめている), 式 (14)のQ $(\mathrm{t})$ を求めた。 $\mathrm{t}_{\imath}$. $\mathrm{V}$ は長さの次元を持っており， $t \iota \cdot \mathrm{V}$ と次式で定義され る $\mathrm{L}_{\mathrm{ME}}$ は图ー12(○印)に示すように密接に関係している
ことがわかった。

$$
\begin{aligned}
\mathrm{t}_{l} \cdot \mathrm{V} & =0.131 \mathrm{~L}_{\mathrm{ME}} \\
\mathrm{t}_{l} & : \mathrm{hr}, \mathrm{V}: \mathrm{m} / \mathrm{sec}, \mathrm{L}_{\mathrm{ME}}: \mathrm{km} \\
\mathrm{L}_{\mathrm{ME}} & =\frac{\mathrm{L}}{2 \mathrm{~N}-1} \sum_{\mathrm{J}=1}^{\mathrm{N}}(\mathrm{J}-1) \mathrm{C}(\mathrm{N}, \mathrm{J})
\end{aligned}
$$

$\mathrm{L}_{\mathrm{ME}}$ は, 平均的河道網における各単位地域の出口から 河道網末端に至る距離の平均值を意味している.

地形図を実测して得られる $\mathrm{L}_{M E}$ は次式で与えられる。 式（21）と区別するためにを付している.

$$
L_{M E} \frac{\sum_{i=1}^{2 N-1} L_{1}}{2 N-1}
$$

$K \cdot v$

$$
t_{l}(3.6 v)(\mathrm{km})
$$

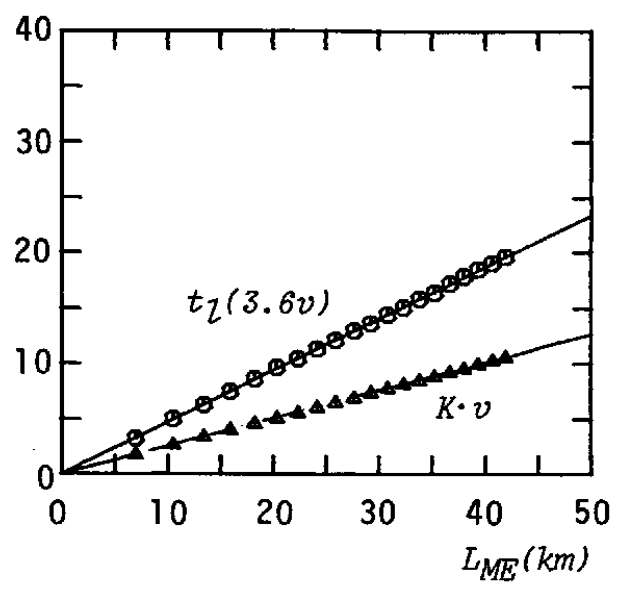

区-12 
L

$L_{M E}$ と L'MEを比較している. L'MEを期待値とするならば

L'MEはその実現値と考えられる.

式（9）を用いて式（18）を書き直す.

$$
\mathrm{L}_{\mathrm{ME}}=\frac{1.273 \mathrm{At}^{0.6} \sum_{\mathrm{j}=1}^{\mathrm{N}}(\mathrm{J}-1) \mathrm{C}(\mathrm{N}, \mathrm{J})}{\left(\mathrm{M}_{\mathrm{N}}+1\right)(2 \mathrm{~N}-1)}
$$

分子の $1.273 \mathrm{At}^{0.6}$ を除いた部分を

$$
\mathrm{L}_{\mathrm{MEI}}=\frac{\sum_{\mathrm{J}=1}^{\mathrm{N}}(\mathrm{J}-1) \mathrm{C}(\mathrm{N}, \mathrm{J})}{\left(\overline{\mathrm{M}}_{\mathrm{N}}+1\right)(2 \mathrm{~N}-1)}
$$

とおいて $\mathrm{L}_{\mathrm{ME1}}$ と $\mathrm{N}$ の関係を図ー13に示す， $\mathrm{L}_{\mathrm{ME1}}$ の值は $\mathrm{N}$ の值か極端に小さい場合を除き，約 0.5 となっている. したがって， $\mathrm{L}_{\mathrm{ME}}$ と $\mathrm{A}_{t}$ の関保式として次式を得る.

$$
\mathrm{L}_{\mathrm{ME}}=0.671 \mathrm{At}^{0.6}
$$

$$
\mathrm{L}_{\mathrm{ME}}:(\mathrm{km}), \mathrm{A}_{t}:\left(\mathrm{km}^{2}\right)
$$

また，迤れ時間 $\mathrm{t}_{\text {}}$ と集水面積 $\mathrm{A}_{t}$ 間の関係式として次式 を得る。

$$
\begin{aligned}
& \mathrm{t}_{\iota}=0.083 \mathrm{At}^{0.6} / \mathrm{V} \\
& \mathrm{t}_{\iota}:(\mathrm{hr}), \mathrm{V}:(\mathrm{m} / \mathrm{s}), \mathrm{A}_{t}:\left(\mathrm{km}^{2}\right)
\end{aligned}
$$

図一12の $\triangle \mathrm{N}^{2}$ 貯留係数に関して $\mathrm{K} \cdot \mathrm{V} \sim \mathrm{L}_{\mathrm{ME}}$ の関係を

図示している. 図より次の関係式が求まる。

$$
\mathrm{K} \cdot \mathrm{V}=0.254 \mathrm{~L}_{\mathrm{ME}}
$$

$$
\mathrm{V}:(\mathrm{m} / \mathrm{s}), \mathrm{L}_{\mathrm{ME}}:(\mathrm{km}), \mathrm{K}:\left(\mathrm{mm}^{1-\mathrm{P}}, \mathrm{hr}^{\mathrm{P}}\right)
$$

$\mathrm{K}$ と $\mathrm{A}_{t}$ に関しては，次式を得る。

$$
\mathrm{K}=0.17 \mathrm{At} \mathrm{t}^{0.6} / \mathrm{V}
$$

$\mathrm{V}:(\mathrm{m} / \mathrm{s}), \mathrm{A}_{t}:\left(\mathrm{km}^{2}\right), \mathrm{K}:\left(\mathrm{mm}^{\mathrm{I}-\mathrm{P}}, \mathrm{hr}^{\mathrm{P}}\right)$

一方, 貯留指数 $\mathrm{P}$ に関しては, 集水面積 $\mathrm{A}_{t}$ や平均距離 $\mathrm{L}_{\mathrm{ME}}$, 伝播速度により多少変化するが, $\mathrm{P}=0.8 の$ 值を得 た.

\section{LMEI}

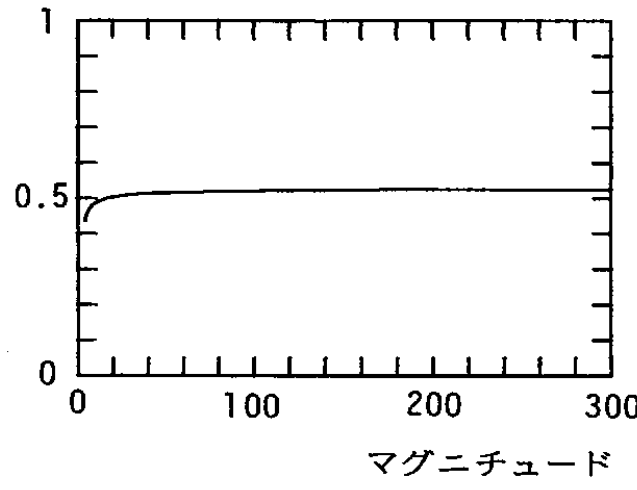

図-13
图ー14は，表一 1 の後志利別川を对象に，集水面積 $\mathrm{A}_{t}=714.7(\mathrm{kmm})$, 平均河道長 $\mathrm{L}_{\mathrm{ME}}=30.2(\mathrm{~km})$ を与之て, $\mathrm{V}=1.0(\mathrm{~m} / \mathrm{s}), \quad 0.5(\mathrm{~m} / \mathrm{s})$ とした時, 式 (15)

(実線) と賍留関数法 (破線)の計算結果を示している. 良好な結果が得られている。

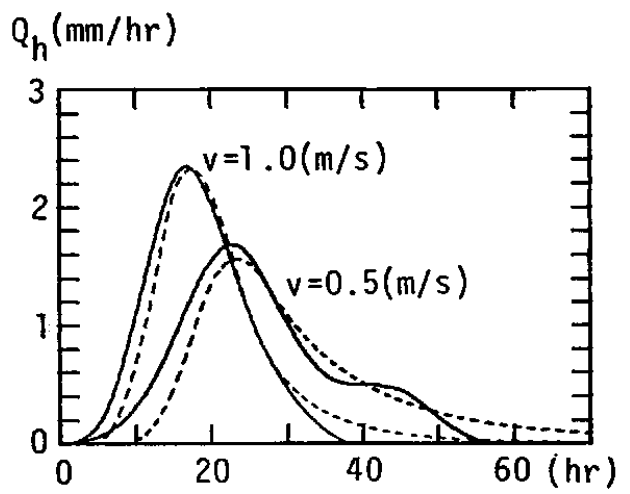

実線：式 (15) 破線：眝留関数法 区一14

\section{IV. まとめ}

河道網における集水過程について賋留関数法を適用し て, 次の結果を得た。

$$
\begin{aligned}
& \mathrm{t}_{\iota}=0.131 \mathrm{~L}_{\mathrm{ME}} / \mathrm{V} \\
& \mathrm{K}=0.254 \mathrm{~L}_{\mathrm{ME}} / \mathrm{V} \\
& \mathrm{P}=0.8 \\
& \mathrm{t}_{\imath}:(\mathrm{hr}), \mathrm{V}:(\mathrm{m} / \mathrm{s}), \mathrm{L}_{\mathrm{ME}}:(\mathrm{km}), \\
& \mathrm{K}:\left(\mathrm{mm}^{\mathrm{I}} \mathrm{P} \cdot \mathrm{hr}^{\mathrm{P}}\right)
\end{aligned}
$$

ここに， $\mathrm{t} ， \mathrm{~K}, \mathrm{P}$ ，は眝留関数法に含まれる遅れ時間， 販留係数及U゙貯留指数である。 $\mathrm{L}_{\mathrm{ME}}$ は流域内の各単位流 域加流域末端まで至る平均距離で，Vは洪水流の伝播 速度である。これまで， $\mathrm{t}$ ， $\mathrm{K}$ を流域の特性量で評価す る際に，流域の重心と流域末端までの距離あるいは，主 流長などと河道勾配を組み合わせた経験式がいくつか提 案されているが'14), 本論文の結果はこれらの経験式に理 論的根抛を与えるものと思われる。本論文でとり上げた 集水過程は, 洪水流の伝播速度を一定する極好て単純な モデルである．河道内の流水の平均流速の実測值をみて

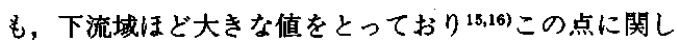
ては今後検討したい. 


\section{参考文献}

1) Sherman, L.W. : The Relation of Hydrograph of Runoff to Size and Character Drainage, Trans. A.G.U., 13, 1932

2) Horton, R.E. : Erosional Development of Streams and their Drainage Basin, Hydrophysical Approach to Quantitative Morphology, Bull. Geol. Am. Vol.56, pp275-370, 1945

3) Strahler, A.N. : Quantitative Geomorphology of Drainage Basins and Channel Networks, in V.T.chow(ed.), Hand Book of Applied Hydrology, Sec. 4-II, McGraw-Hill Book Company, New York, 1964

4) Chow, V.T. (ed.) : Handbook of Applied Hydrology, Sec. 4-II, McGraw-Hill Book Company, New York, 1964

5 ) 石原藤次郎, 高棹环馬, 瀨能邦雄 : 河道配列の 統計則に関する基脴的研究, 京都大学防災研究所年 報, Vol.12, 1969

6）藤田睦博 ： 流域地形棈造とその統計則に関する 研究, 土木学会論文報告集, Vol. 234, 1975

7) 藤田睦博 : 河道網における支流の分布特性に関 する研究，土木学会論文報告集, Vol. 246, 1976
8）岩佐義朗，小林信久： マグニチュード理論によ る統計則と指標, 土木学会論文報告集, Vol．273, 1978

.9）岩佐義朗，小林信久： マグニチュード理論に基 づく流域地形則およびその位数理論との関連性, 土 木学会論文報告某, Vol. 273, 1978

10) Md. Sayeedul Islam Khan, Fusetsu, Takagi and Shohei Adachi : On the StorageDischarge Relationships in the Flat Land, Proc. of JSCE, No.297, 1980

11）藤田睦博 ： 斜面長の変動を考虑した眝留関数法 に関する研究，土木学会論文集，314号，1981

12) Shreve, R.L : Variation of Mainstream Length With Basin Area in River Networks, W.R.R., Vol. 10, No.6,1974

13）高山茂美 ： 河川地形, 共立出版, 1974

14）舘谷清・山口甲：北海道の治水，(財）北海道河 川防苂研究センター, 1987

15）山辺功二： 水流の水理幾何についての一考察, 水温の研究, $15(2), 1971$

16) Leopold, L.B.他 : River Channel Patterns : Braided, Meandering and Straight, Geological survey professional paper 282-B, 1957

舘谷清
昭和 28 年 $\quad \begin{aligned} & \text { 北海道大学工学部土木工学科卒業 } \\ & \text { 昭和 } 28 \text { 年 }\end{aligned}$

